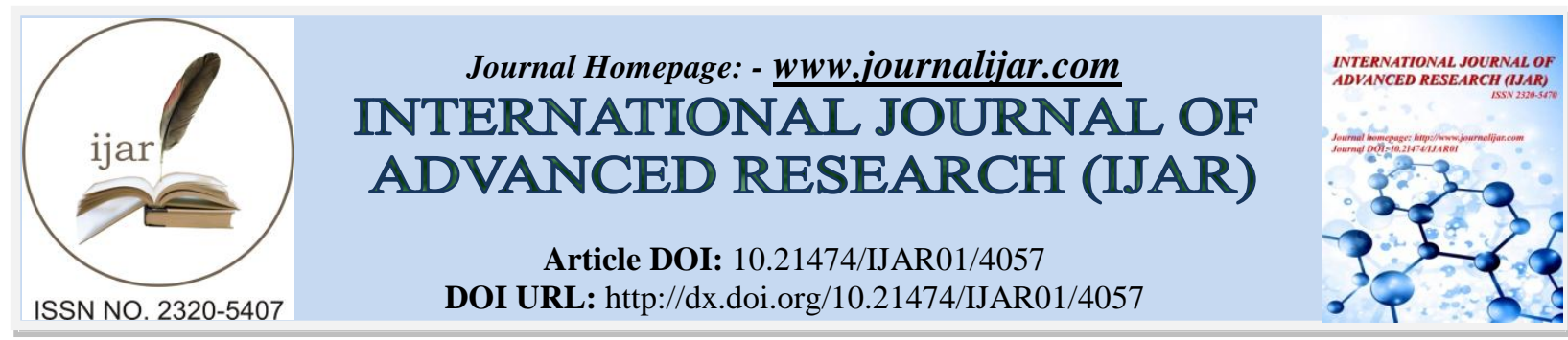

RESEARCH ARTICLE

\title{
SURVIVAL OF XANTHOMONAS AXONOPODIS PV. MANIHOTIS IN WEED SPECIES AND IN CASSAVA DEBRIS : IMPLICATION IN THE EPIDEMIOLOGY OF CASSAVA BACTERIAL BLIGHT.
}

Fanou André Antoine ${ }^{1}$, Zinsou Amégnikin Valerien ${ }^{1}$ and Wydra Kerstin ${ }^{2}$

1. Faculty of Agronomy, University of Parakou BP 123 Parakou, Republic of Benin. West Africa.

2. Chair Plant Production and Climate change, Erfurt University of Applied Sciences, Leiziger Str. 77, 99085 Erfurt, Germany.

\section{Manuscript Info}

(...........................

Manuscript History

Received: 26 February 2017

Final Accepted: 21 March 2017

Published: April 2017

Key words:-

Epiphytically, inoculum source, bacteria, cassava, disease

\section{Abstract}

Weeds from 10 different families were collected weekly from a cassava field previously inoculated with an antibiotic resistant strain of Xanthomonas axonopodis pv. manihotis (Xam) and screened for presence of the pathogen. In the glasshouse, weeds transplanted in pots were infiltrated with a highly virulent marked Xam strain, and the development of the Xam population was quantified.

Under field conditions, Xam survived epiphytically for at least 30 days at moderate concentration on Brachiaria deflexa (Poaceae), Mariscus alternifolius (Cyperaceae), Pupalia lappacea (Amaranthaceae) and Solanum nigrum (Solanaceae), whereas lower Xam concentrations were determined on Dactyloctenium aegyptium (Poaceae), Talinum triangulare (Portulacaceae) and Tridax procumbens (Asteraceae) within 30 days. Some other weeds supported a shorter survival time of the pathogen, such as Cyathula prostrata (Amaranthaceae), Digitaria horizontalis (Poaceae), Euphorbia heterophylla (Euphorbiaceae) and Physalis angulata (Solanaceae).

After infiltration of leaves with Xam suspension in the glasshouse, Vernonia cinerea (Asteraceae), Dactyloctenium aegyptium and Brachiaria deflexa supported survival of Xam for 60 days.

Under field conditions as well as in the glasshouse, none of the weed species developed disease symptoms similar to Cassava Bacterial Blight (CBB), so that, alternative host could not be identified among the weed species studied. However, since the pathogen survived or even multiplied on some weed species, these plants may constitute an inoculum source from which the bacteria can be transferred to cassava plants.

The role of infected debris in the survival of Xam in the field was studied by keeping infected cassava leaves on the soil surface, by covering infected cassava leaves with soil, or by burying the infected leaves at $25 \mathrm{~cm}$ to $30 \mathrm{~cm}$ soil depth. In the glasshouse, debris mixed with soil and unmixed debris with soil were subjected to different water 
regimes to simulate the seasons.

Our investigations proved that the survival period of Xam in debris on the soil surface was negatively correlated with rainfall. During the trial of 1996, the total rainfall was less than the rainfall in 1997, and the survival of Xam in debris on the soil surface reached at least 60 and 45 days, respectively. When the debris were covered with soil or buried in soil, the survival reached only 30 days. The survival reached less than 60 days when debris mixed with the soil were moistened three times a week. Under dry conditions, Xam survived for more than 150 days. When soil was contaminated by a pure bacterial suspension of Xam, the bacteria survived only for three weeks at very low numbers. Thus, infected debris on the soil surface could conserve the pathogen for a long period depending to the environmental conditions and constitute an inoculum source for a new plantation.

Copy Right, IJAR, 2017,. All rights reserved.

\section{Introduction:-}

Cassava bacterial blight (CBB) is a disease widely distributed in cassava production countries of the world and remains one of the most devastating diseases of cassava (Lozano and Sequeira, 1974; Dedal et al., 1980; Leu, 1978; Fanou, 1999; Wydra et al., 1998). The causal agent, Xanthomonas campestris pv. manihotis recently reclassified as Xanthomonas axonopodis pv. manihotis (Xam) (Vauterin et al., 1995), is a seedborne pathogen (Persley, 1979; Daniel and Boher, 1981; 1985b; Elango and Lozano, 1980). Infected cuttings as planting materials (Maraite and Meyer, 1975; Daniel and Boher,1985b; Bani, 1990; Fanou, 1999) are also dispersion means of the pathogen. In all cassava production areas, weeds are a serious problem reducing cassava yield (65\%) and marketable value of cassava roots (Akobundu, 1990). They may serve as habitat for insects and inoculum source for pathogens, especially in cassava fields close to a bush fallow or in fields which are weeded late. Weeds have been proved to serve as reservoirs of bacterial pathogens (Cafati and Saettler, 1980; Latorre and Jones, 1979; Mcarter et al., 1983; Gitaitis et al., 1998; Schuster and Coyne, 1974; Jones et al., 1986). The survival of Xam on weeds was reported in several studies (Ikotun, 1981; Daniel and Boher, 1985b; Elango and Lozano, 1981). However these authors could not identify alternative host among the weed species studied. Several other weed species were not yet proved to play a role in the survival of Xam or to act as hosts of the pathogen.

During the plant vegetation, cassava leaves constantly fall and remain as debris on the soil and incorporated in the soil for a long time. Especially cultivars highly susceptible to CBB shed their infected leaves. In most cultivation systems, debris from previous cassava crops are neither burnt nor buried, while in other systems, leaves are partly buried in the furrows when ridges are made. The survival time of the pathogen on and in these infected leaves and the role of infected debris in the perpetuation of the disease are questions of interest in the epidemiology of CBB and should be considered in disease management. Survival of Xam in debris on the soil surface under controlled conditions (Persley, 1977) and under field conditions (Daniel and Boher, 1985b) was studied, but these authors did not test the survival period of the pathogen when the debris are buried. Vertical distribution of Xam in naturally infested soil was investigated in Colombia (Ikotun, 1982), but this author did not report how long the pathogen survived in such conditions. In Venezuela, Marcano and Trujillo (1984) conducted experiments on survival of Xam in cassava debris buried at $10 \mathrm{~cm}$ depth under laboratory and field conditions during the dry season but they did not conduct experiments under field conditions during the rainy season. Therefore, a clarification was needed and more detail studies under field and controlled conditions were necessary.

The present studies were undertaken to determine whether and to which extent weeds are lodging Xam and contribute to the dissemination of the pathogen, and whether some weeds can be regarded as alternative hosts of Xam. On the other hand, our studies aimed to determine the survival of Xam under various ecological conditions in and on leaves on the soil surface and when leaves are buried.

\section{Materials and Methods:-}

The studies were conducted at the International Institute of Tropical Agriculture (IITA), Abomey-Calavi, Benin, in the coastal forest savanna transition zone. The average annual rainfall ranges between 1200 to $1400 \mathrm{~mm}$ spread from March to July and from September to October intercalated by a small dry season in August. The long dry period 
extends from November to March. The soil is a sandy loam with $\mathrm{pH} 6.9$.

\section{Survival of Xam on weed Species:-}

Planting material, plantation and spraying in the field:-

Cassava cuttings from apparently healthy plants of the local cultivar "BEN 86052" were used to establish a cassava field. Cuttings of approximately $20 \mathrm{~cm}$ length were planted on ridges at a spacing of $1 \mathrm{~m} \mathrm{x} 1 \mathrm{~m}$ in a plot of $60 \mathrm{~m} \times$ $20 \mathrm{~m}$ in June 1996. The field was not weeded.

One month after planting, the abaxial surface of cassava leaves were sprayed with a suspension of a marker strain of Xam GSPB 2506 resistant to streptomycin and rifampicin. This strain is a spontaneous mutant which was created from the wild strain IITA3c by cultivating it in Rhodes (1959) liquid medium with gradually increasing concentrations of both antibiotics. For inoculum production, the strain was cultivated on nutrient glucose agar (nutrient broth $8 \mathrm{~g} / \mathrm{l}$, glucose $11 \mathrm{~g} / \mathrm{l}$, yeast extract $3 \mathrm{~g} / \mathrm{l}$, agar $15 \mathrm{~g} / \mathrm{l}, \mathrm{pH}=7.2$ ), and spraying was performed in the evening at the concentration of $10^{7}$ cells $/ \mathrm{ml}$.

\section{Planting and spray inoculation of weed species in the glasshouse:-}

Weed species common in cassava fields and used in this experiment (Table 1) were collected from fields at IITA, Benin, four weeks after the beginning of the rainy season and transplanted in pots containing field soil. For each species, five pots were planted each with one plant and kept in the glasshouse. The highly virulent Xam strain GSPB 2511 marked with resistance against streptomycin and rifampicin was used to inoculate the plants to determine whether the infiltrated leaves would develop similar symptoms to CBB. The concentration of the suspension was adjusted to $10^{8}$ cells $/ \mathrm{ml}$ with a spectrophotometer at a wave length of $660 \mathrm{~nm}(\mathrm{OD}=0.06)$. Subsequently, the concentration was adjusted to $10^{7}$ cells $/ \mathrm{ml}$ by tenfold dilution with tap-water before spraying. Spray inoculation was performed using a glass sprayer (Hokawat and Rudolph, 1991) connected to an electric pump. The inoculum was infiltrated into all the leaves.

\section{Collection of leaf samples:-}

For the field experiments, weeds which are frequently found in cassava fields were selected (Table 1). The weeds were identified according to Akobundu and Agyakwa (1987). Leaf samples of weeds and of cassava were taken weekly from the day following the spraying. At each sampling date, leaves of each weed were separately collected in a paper bag and transferred in the laboratory.

In the glasshouse, two to three inoculated leaves were collected from each plant. The leaves were wrapped in aluminum foil. Each aluminum foil containing the leaves was coded following the code number of the weed species. The leaves were collected every two weeks from the day following leaf infiltration. After collecting the leaves of one species, scissors and hands were sterilized with $70 \%$ ethanol.

\section{Pathogen Detection:-}

After weighing each sample, the leaves were macerated in a mortar in $45 \mathrm{ml}$ of sterile $0.01 \mathrm{M} \mathrm{MgSO} 4$ solution. Subsequently, the macerate was filtrated through cheese-cloth and the filtrate was centrifuged for 15 min at $5210 \mathrm{x}$ g. The supernatant was decanted and the pellet suspended in $5 \mathrm{ml}$ of $0.01 \mathrm{M}$ of MgSO 4 solution. Serial dilutions of the initial suspension were prepared and $0.1 \mathrm{ml}$ of each dilution was plated on Nutrient Broth Agar containing 100 ppm each of streptomycin and rifampicin and $200 \mathrm{ppm}$ of cycloheximide. The agar was additionally enriched with the fungicide Benomyl to avoid overgrowing of Xam colonies by fungi which make counting of Xam colonies impossible. Therefore, $250 \mathrm{mg}$ of Benomyl were suspended in $10 \mathrm{ml}$ of a mixture of methanol and distilled water $12.5: 87.5$, and $8 \mathrm{ml}$ of this solution were mixed with $1000 \mathrm{ml}$ of agar. The agar plates were incubated at $30{ }^{\circ} \mathrm{C}$ for 48-72 hours, and the number of Xam colonies was counted when possible. The arithmetic mean of colony forming unit (CFU) per agar plates and per gram-sample was calculated.

\section{Survival of Xam in Debris:-}

\section{Cassava "tree" production and spraying:-}

The cultivar BEN 86052 which is known to be susceptible to CBB was used to produce cassava "tree" in the glasshouse following the method described by Haug and Mégevand (1989). Cuttings of $20 \mathrm{~cm}$ length were treated in hot water at $52{ }^{\circ} \mathrm{C}$ for $5 \mathrm{~min}$. After this treatment, the basal part of each cutting was dipped into a solution of the hormone 3-indolebutyric acid ( $1 \mathrm{~g}$ of hormone in $100 \mathrm{ml}$ of ethanol $+900 \mathrm{ml}$ of water) and planted into coconut substrate contained in mulching plastic. About 72 cuttings were planted into each artificial trank. An automatic 
system supplied water to the plants in the glasshouse until the end of the experiment. When the plants were one month old, they were sprayed with the marked strain GSPB 2506 suspension at the concentration of $10^{7}$ cells $/ \mathrm{ml}$.

\section{Collection of infected Leaves:-}

About ten days after spraying, the symptoms of cassava bacterial blight started to appear. The following days, the symptoms became more and more pronounced before the leaves wilted and dropped. As soon as the infected leaves fell, they were collected each day and dried at room temperature until most of the leaves had dropped.

\section{Experimental design and trial Installation:-}

In the trial of 1996, a simple block design containing the three treatments was used to conduct the experiment in the field. In the first treatment, the infected leaves were placed on the soil surface on an area of $1 \mathrm{mx} 1 \mathrm{~m}$. In the second treatment, the leaves placed on the soil surface were covered with top soil on an area of $1 \mathrm{~m} \mathrm{x} 1 \mathrm{~m}$. In the third variant, the leaves were buried $25 \mathrm{~cm}$ to $30 \mathrm{~cm}$ deep in an area of $1 \mathrm{~m} \mathrm{x} 1 \mathrm{~m}$.

In the second trial performed in 1997, instead of directly placing the leaves on or in the soil, a fine-knit net enclosed the leaves. About $10 \mathrm{~g}$ of leaves were mixed with $500 \mathrm{~g}$ of soil and put in a small net which was attached to a stick for easier sampling. A total of 24 samples were prepared for each variant and arranged like the experiments of 1996. A roof with palm leaves $1 \mathrm{~m}$ above the ground was constructed over the experiment area to simulate a cassava field environment.

In the glasshouse, the trial was performed in pots with 8 variants. The experiment was designed to be conducted during one year. Therefore, each variant was repeated twelve times.

\section{Variants:-}

1. Infected leaves mixed with soil, watered three times per week during 6 months and then not watered (T1)

2. Infected leaves mixed with soil, watered three times per week during 12 months (T2)

3. Infected leaves mixed with soil, watered three times in one week, not watered during the following week, followed by alternate weekly watering and not watering (T3)

4. Infected leaves mixed with soil and kept without watering (T4)

5. Infected leaves in pots without soil, watered three times per week during 6 months and then not watered (T5)

6. Infected leaves in pots without soil, watered three times per week during 12 months (T6)

7. Infected leaves in pots without soil, watered three times in one week, not watered the following week, followed by alternate weekly watering and not watering (T7)

8. Infected leaves in pots without soil, without watering (T8)

In the variants "infected leaves plus soil", $2 \mathrm{~kg}$ of soil were mixed with $15 \mathrm{~g}$ of infected leaves, while for the other variants, only $15 \mathrm{~g}$ of leaves were used.

\section{Samples Collection:-}

Samples were collected monthly beginning on the day of trial installation. A sampling stick was used to take the samples at three different places for each variant. Both infected leaves and soil were taken. In the second trial, the samples were collected every second week for each variant, and three nets were used. The collected samples were kept in aluminum foil and brought to the laboratory for pathogen detection. Samples from the glasshouse were also collected monthly from the day the trial had been installed. For each variant, the soil and leaves of one entire pot were used.

\section{Pathogen Detection:-}

Samples were pounded in a mortar and after mixing well, sub-samples of $5 \mathrm{~g}$ were suspended in a few $\mathrm{ml}$ of $0.01 \mathrm{M}$ $\mathrm{MgSO} 4$ and agitated. In the field trial of 1997, the three samples of each variant were treated separately, pounded, and a sufficient quantity of magnesium sulphate solution was added to the entire sample and agitated. The liquid was filtered and then centrifuged at $5210 \mathrm{x} \mathrm{g}$ for $15 \mathrm{~min}$.

The contents of each pot from the glasshouse were weighed and macerated. The samples with soil were mixed very well and a sub-sample of $100 \mathrm{~g}$ was suspended in sterile magnesium sulphate solution. After mixing, the liquid was filtered and centrifuged at $5210 \mathrm{x}$ g for $15 \mathrm{~min}$. The supernatant of both sample categories was decanted and the pellet was suspended in $5 \mathrm{ml}$ of magnesium sulphate solution. Serial dilutions were prepared and $0.1 \mathrm{ml}$ of each 
dilution was plated onto Nutrient Glucose Agar enriched with 100 ppm of streptomycin and rifampicin and 200 ppm of cycloheximide. In the second trial, Benomyl $(8 \mathrm{ml} / 1$ containing $200 \mathrm{mg}$ ) was added to the agar. The agar plates were incubated at $30^{\circ} \mathrm{C}$. Two or three days later, the Xam colonies were counted.

Direct survival of Xam cells in the soil was tested by pouring a bacterial suspension with a concentration of $10^{8}$ cells/ml on the soil in three pots which were kept under glasshouse conditions $\left(25-30{ }^{\circ} \mathrm{C}\right.$ and $\left.65-95 \% \mathrm{RH}\right)$. Each week, soil samples were collected to detect Xam. For the detection, the same method as described above was followed.

\section{Results:-}

Survival of Xanthomonas axonopodis pv. manihotis on common weeds under field Conditions:-

On 15 common weed species of South Benin (Table 1) the survival of Xam was studied. These weed species are usually associated with cassava and occur in all regions of South Benin. The development of Xam populations on these weeds in an inoculated cassava field was followed over 45 days.

One day after artificial inoculation of the cassava plants by a bacterial suspension, Xam was detected on 3 species in low concentration, with less than $10^{2}$ CFU per g leaf fresh weight (Table 2). Only Digitaria horizontalis showed a high epiphytic population (nearly $10^{3} \mathrm{CFU} / \mathrm{g}$ ) compared to the other species. One week after inoculation, the number of weeds lodging Xam epiphytically increased to nine of fifteen species (60\%). The population was higher than $10^{3} \mathrm{CFU} / \mathrm{g}$ on Solanum nigrum, and $2 \mathrm{X} 10^{3} \mathrm{CFU} / \mathrm{g}$ on Mariscus alternifolius. Two weeks after spraying, Xam was detected on $73 \%$ of the weeds with bacterial numbers from 10 to $1.5 \times 10^{3} \mathrm{CFU} / \mathrm{g}$. Again Solanum nigrum harbored the highest population followed by Mariscus alternifolius. Up to 30 days, after inoculations an increase of Xam populations was observed on Brachiaria deflexa and on Pupalia lappacea, whereas bacterial numbers decreased on the other weeds. After 37 and 45 days, Xam could not be detected on any of the weed species. Typical CBB symptoms were never observed on any of the weed species. On four weed species, Vernonia cinerea, Mucuna cochinchinensis, Cassia mimosoides and Commelina benghalensis, Xam was never detected during our investigations.

\section{Survival of Xanthomonas axonopodis pv. manihotis on common weeds under glasshouse Conditions:-}

Bacterial infiltration by an atomizer with pressure was used to inoculate 13 weed species which were kept in the glasshouse during the experiment. One day after inoculation, Xam proved to be present on all weed species. On the following days, a multiplication of Xam was determined on all the weeds (99\%) except in Pupalia lappacea where the initial Xam population decreased slightly (Table 3). Talinum triangulare was the species with the highest population $\left(3.2 \times 10^{6} \mathrm{CFU} / \mathrm{g}\right)$. The multiplication rate was also high in Vernonia cinerea with a population increase of 50 times compared to day 1, while the population in Pupalia lappacea was decreased by half 30 days after inoculation. The initial multiplication of Xam until 15 days after inoculation did not continue on most of the species, except on Brachiaria deflexa up to $30 \mathrm{dpi}$, Commelina erecta, Mariscus alternifolius, Mucuna cochinchinensis and Talinum triangular up to 25 dpi. Sixty days after infiltration of leaves, $77 \%$ of the weed species did no longer lodge the pathogen, while Xam was still detected on Dactyloctenium aegyptium and Brachiaria deflexa belonging to the family of Poaceae, and Vernonia cinerea belonging to the family of Asteraceae. The survival of Xam did not reach up to 2.5 months in or on any of the weed species. Despite of the use of highly virulent strain of Xam to inoculate the weed species, typical CBB symptoms were never observed.

\section{Survival of Xanthomonas axonopodis pv. manihotis in infected Debris:-}

The survival of Xam in infected cassava debris incorporated in the soil was studied under field and glasshouse conditions. In the first field experiment in 1996, cassava debris was laid on the soil surface, covered by soil or incorporated in the soil without shadowing. The survival of Xam reached at least 60 days but not 90 days in infected debris laid on the soil surface (Figure 1). However, when the debris on the soil surface were slightly covered with top soil, Xam was detected only until 30 days. In debris buried at $25 \mathrm{~cm}$ to $30 \mathrm{~cm}$ of soil depth, Xam was detected in comparably low numbers until 30 days after starting the experiment.

In a repeated trial in the rainy season of the following year (1997), cassava debris on and in the soil in nets was kept under shadow. Samples were taken every second week. Until 30 days, the CFU/g of debris placed on the soil surface 
did not change considerably, but decreased rapidly during the following two weeks, and fell to zero after 60 days (Figure 2). When the debris were covered with soil, the survival of Xam decreased more rapidly to a very low value (ca 14 CFU/100 g soil-debris) at 45 days. When the debris were buried in 25 to $30 \mathrm{~cm}$ of soil depth, the decline of the population from the fifteenth to thirtieth day was very rapid and the survival until 45 days was also lower than in the other variants.

In the glasshouse, infected cassava debris was submitted to different water regimes. Xam could not be detected after 60 days when the debris mixed with soil were moistened three times a week (variants T1, T2 and T3) (Figure 3). No difference was found between watering every week (variants T1 and T2) and watering every second week (variant T3). When unmixed debris were moistened as above, the pathogen was detected until 60 days (variants T5, T6 and T7), but did not survive until 90 days. When the debris mixed with soil and not mixed debris were kept under dry conditions, the survival of Xam was longer compared to the watered variants, and bacteria survived more than 150 days in debris in the soil (variants T4), while the survival in dry debris without soil reached at least 120 days (variant T8).

Direct survival of Xanthomonas axonopodis pv. manihotis in soil without plant debris

The survival of Xam in soil contaminated by a bacterial suspension under glasshouse conditions was limited to 21 days (Table 4). Already after one week, only $4 \mathrm{CFU/g}$ soil were detected.

\section{Discussion:-}

Under field conditions, most of the collected weed leaves harbored the pathogen epiphytically at concentrations of $10^{1}$ to $7 \times 10^{3} \mathrm{CFU} / \mathrm{g}$ leaf up to 30 days. The percentage of weeds lodging the bacterium increased from $26 \%$ one day after inoculation to a maximum of $73 \%$ two weeks after spray- inoculation of the cassava plants. At that time, a high multiplication of the epiphytic Xam population occurred on cassava leaves and water-soaked angular leaf spots had developed on all cassava plants. The rainfall recorded in August 1996 (Figure 4) and early morning dew may have contributed to the contamination, the survival and multiplication of Xam on or in most of the weeds. High CFU counts were still recorded after 3 weeks on Pupalia lappacea, Mariscus alternifolius, Brachiaria deflexa and Solanum nigrum belonging to the family Amaranthaceae, Cyperaceae, Poaceae and Solanaceae, respectively. The non-detection of Xam on Mucuna cochinchinensis, Commelina benghalensis, Cassia mimosoides, Vernonia cinerea and the short survival on Physalis angulata and Euphorbia heterophylla under field conditions, may be due to the physiological stage of these plants, or to the differences in availability of nutrients and humidity on leaf surfaces, or a low carrying capacity of some weed species and rain-washoff of bacterial cells from the leaf surfaces. Studying the nutrients on leaf surfaces, Derridj (1996) and Jacques (1996) found more nutrients on older leaf surfaces than on younger ones. The high content of nutrients on mature leaves may provide optimal multiplication conditions and raise the level of epiphytic population of Xam on leaves such as we found on cassava old leaves, in another studies (Fanou, 1999). Also differences of the structure of leaves favouring quick penetration of bacteria into intercellular spaces of some genotypes and slow penetration in others, could also explain the non-finding of Xam on some weed species. For example, differences in thickness and permeability of cuticles of stomata, hydathodes and trichomes were observed (Schönherr and Baur, 1996).

When an highly virulent Xam strain was infiltrated into the weed leaves in the glasshouse, Xam multiplied in $99 \%$ of the tested weeds during the first two weeks, with a high increase on Euphorbia heterophylla, Physalis angulata,

Talinum triangulare and Tridax procumbens where more than $10^{6} \mathrm{CFU} / \mathrm{g}$ fresh weight were reached. Comparing the environments, the Xam populations on weed species were higher in glasshouse than at field conditions. Under field conditions, the penetration of Xam in the leave tissues might be probably limited and the living population on leave surfaces would be affected by the inhibitory effect of ultraviolet radiation. On the other hand, most of the bacteria might be washed off from the leave surfaces by the rain under field conditions. However, none of the infiltrated weeds developed symptoms similar to CBB. The bacteria obviously survived and multiplied without causing apparent damage to the plants. These observations are in concordance with those of Hirano and Upper (1983) who reported that phytopathogenic bacteria frequently reside epiphytically on non-host plant species. Considerable numbers of bacteria survived, on/in Vernonia cinerea, Dactyloctenium aegyptium and Brachiaria deflexa for more than 60 days. The present findings confirm earlier results of Ikotun (1981) and Amusa et al. (1992) that Xam does not have alternative hosts. On the other hand, Manihot glaziovii, variegated ornamental cassava, Euphorbia pulcherrima and Pedilanthus tithymaloides (Dedal et al., 1980), Amaranthus species, Panicum fasciculatum, Sida species, Sorghum halepense and several species belonging to the Euphorbiaceae in Venezuela 
(Marcano and Trujillo, 1982), were identified as possible alternative hosts for Xam. In Colombia, among the weed species tested, Amaranthus dubia (Amaranthaceae) lodged many Xam cells (Elango and Lozano, 1981). The present studies also revealed that species belonging to the Amaranthaceae and Dactyloctenium aegyptium supported the survival of Xam better than some other weed species. A long survival of Xam was recorded on Dactyloctenium aegyptium (Poaceae) under field conditions as well as in the glasshouse. On the contrary, Elango and Lozano (1981) reported that graminaceous weeds rarely carried the pathogen.

The epiphytical survival of Xam on weeds is in concordance with the previous reports of Daniel and Boher (1978), Persley (1978), Elango and Lozano (1981), Daniel and Boher (1985a), Daniel and Boher (1985b), Lozano (1986), Boher and Verdier $(1994)$ and Fanou et al. $(1998,2001)$ who reported that Xam has an epiphytical phase on cassava plants or/and on weeds.

The duration of the survival varied greatly depending on to the weed species and the bacterial strain. After sprayinoculated, the pathogen survived only for 12 days in Euphorbia repanda (Euphorbiaceae), 7 days in Ricinus communis (Euphorbiaceae), 5 days in Phaseolus vulgaris (Leguminoseae), Nicotiana tabacum (Solanaceae), Lycopersium esculentum (Solanaceae) and Physalis angulata (Solanaceae), and 3 days in Amaranthus dubius (Amaranthaceae) (Ikotun 1981), while our data showed survival up to 45 days on species of the family Euphorbiaceae and Solanaceae and up to 30 days on species of the family Amaranthaceae. Nevertheless, weeds could not act as important reservoirs for all phytopathogenic bacteria. In fact, attempts to reisolate Erwinia tracheiphila from previous inoculated herbaceous weed species using the stem blot technique, immersion stem segment technique, Immuno affinity isolation etc. were unsuccessful (de Mackiewicz et al., 1998).

The maximal survival period of Xam corresponded to the vegetative cycle of the annual weeds involved in our studies. Thus, Xam could not be detected when the weeds reached the end of their growth cycle and dried. Our studies suggest, that the survival of Xam on or in weeds may play an important role in the spread of CBB during the growing season. In the epidemiology of foliar pathogens, survival of cells on non-host plants, especially weeds, may have a far reaching significance. The role of weeds as inoculum sources for phytopathogens (Hirano and Upper, 1983) and generally for xanthomonads (Rudolph, 1993) for disease development on susceptible hosts was suggested in several cases. In cassava growing areas, weeds are most of the time found close to and between cassava fields. These weeds are the habitat for a wide range of insects (Orthoptera, Coleoptera, Diptera etc.), for certain animals, and serve as niche for insect-feeding birds during the rainy season. The movement of men, insects, birds and animals through contaminated weeds and cassava plantations, especially during or after rain or in the early morning, may contribute to pathogen spread. Strong winds or wind-driven rains may transport the bacteria from weeds to cassava plants, within and among cassava plantations.

In the cassava cropping system, plant debris mostly remain on the soil until the new cropping season starts. Thus, the role of infected debris in the spread of CBB may be considerable. Our investigations showed that the CFU/g of debris and soil decreased rapidly when the debris were covered with soil and even more rapid when they were buried, compared to debris remaining on the soil surface. These results classify also Xam in the first group of Buddenhagen (1965). The survival time depended on the environmental conditions. During the first trial (1996), the total rainfall was less than during the second trial (1997) (Figure 4), and the survival of Xam in debris on the soil surface reached at least 60 days and 45 days, respectively, but it reached only 30 days for both years when the debris were covered with soil or buried in soil. Both survival trials of Xam in debris under field conditions were conducted from August to December. The short survival period of Xam in covered or buried debris recorded during our experiments was similar to those obtained by Thaveechai et al. (1993) who reported survival of Xam for 21 to 49 days in infected cassava tissues buried in the soil under field conditions of Thailand. However longer survival period of 60 days were observed when infected cassava debris were buried in $10 \mathrm{~cm}$ soil depth under field conditions during the dry season (Marcano and Trujillo, 1984). The survival of the pathogen in debris on the soil surface with a high CFU counts compared to the covered or buried debris confirmed the findings of Ikotun (1982) who observed that the survival of Xam was restricted to debris on the soil surface and the upper $5 \mathrm{~cm}$ and of Fanou et al. (2001).

It can be concluded from these data that rainfall and soil humidity play a decisive role in the quick decay of the debris and contribute to the short survival of Xam in debris under high rainfall and high soil humidity. Our experiments with different water regimes in the glasshouse where the survival under high moisture conditions did not reach 60 days confirmed these field results. Under dry conditions in the glasshouse, Xam survived longer than 5 months. These findings are similar to the results recorded by Persley (1977) that Xam survived for up to 180 days in 
debris in soils kept at $30{ }^{\circ} \mathrm{C}$ in the laboratory under dry conditions. According to our results, Xam survived for 120 days in unmixed debris kept under dry conditions in the glasshouse. Other authors reported even longer survival times: the pathogen survived for up to one year without loosing its pathogenicity in highly contaminated cassava debris kept in the laboratory at $25^{\circ} \mathrm{C}$ and at $70 \%$ relative humidity (Daniel and Boher, 1985b; Daniel, 1991), for more than 30 months in dried infected cassava stems (Ikotun, 1977) and for up to 22 months under dry conditions at room temperature (Terry, 1976). Xam could not survive for more than 21 days freely in the soil when a bacterial suspension was poured in the soil. These results concorded with previous reports of Ikotun (1982) that free survival of Xam in soils was poor (21 to 28 days) and of Schuster and Coyne (1974) that few bacteria survive in soil in a free state. It was also reported that other xanthomonads could survive in plant debris in or on the soil as long as the debris was not decomposed (Rudolph, 1993). Thus, Xam could survive long in stem debris of which the decay is slow. Amusa et al. (1992) reported the survival of Xam in debris under Mucuna fallow over 12 months. The present studies clarified in detail the incomplete reports and revealed the survival time of Xam under field conditions in the forest savanna transition zone. In contrast to previous works, our investigations permitted to compare the survival period of Xam in debris on the soil surface and when the debris are covered or buried and also compare the survival of the pathogen in debris under field conditions and controlled conditions with different water regimes. Survival of Xam in leaves without soil subjected to different water regimes was always longer than the leaves with soil under the same water conditions.

It is concluded from these experiments, that in highly contaminated cassava plantations, infected cassava leaves falling at the end of the rainy season, may conserve the pathogen during the 5 to 7 months of the dry period and constitute an inoculum source for the new cropping season, while infected leaves falling during the rainy season can contribute to the dissemination in the field. Wind-driven rain and water splash may transfer the bacteria from infected plant debris to new cassava plantations. Thus, in fields where successive cassava crops are practised, the infected debris on the soil surface may favour the initial infection of lower leaves in close proximity to the soil surface.

Table 1:- Frequently occurring weeds in cassava fields in South-Benin used for survival study of Xanthomonas axonopodis pv. manihotis under field and glasshouse conditions

\begin{tabular}{|l|l|l|l|}
\hline Weed species & Family & Field & Glasshouse \\
\hline Brachiaria deflexa & POACEAE & 1 & + \\
\hline Cassia mimosoides & CAESALPINIACEAE & + & + \\
\hline Commelina benghalensis & COMMELINACEAE & + & 2 \\
\hline Commelina erecta & COMMELINACEAE & - & + \\
\hline Cyathula prostrata & AMARANTHACEAE & + & - \\
\hline Dactyloctenium aegyptium & POACEAE & + & + \\
\hline Digitaria horizontalis & POACEAE & + & + \\
\hline Euphorbia heterophylla & EUPHORBIACEAE & + & + \\
\hline Mariscus alternifolius & CYPERACEAE & + & + \\
\hline Mucuna cochinchinensis & FABACEAE & + & + \\
\hline Physalis angulata & SOLANACEAE & + & + \\
\hline Pupalia lappacea & AMARANTHACEAE & + & + \\
\hline Solanum nigrum & SOLANACEAE & + & - \\
\hline Talinum triangulare & PORTULACACEAE & + & + \\
\hline Tridax procumbens & ASTERACEAE & + & + \\
\hline Vernonia cinerea & ASTERACEAE & + & + \\
\hline
\end{tabular}

${ }^{1}$ Tested ${ }^{2}$ Not tested 
Table 2. Development of Xam populations on different weed species in non-weeded cassava field artificially inoculated with a bacterial suspension of $10^{7}$ cells/ml of the strain GSPB 2506 at the IITA, Benin

\begin{tabular}{|c|c|c|c|c|c|c|c|}
\hline \multicolumn{7}{|c|}{ CFU/g leaf fresh weight* } \\
\hline Weed species & 1 day** & 7 days & 15 days & 21 days & 30 days & 37 days & 45 days \\
\hline B. deflexa & 0 & $8.1 \times 10^{1}$ & $2.4 \times 10^{2}$ & $2.5 \times 10^{3}$ & $7.510^{3}$ & 0 & 0 \\
\hline C. mimosoides & 0 & 0 & 0 & 0 & 0 & 0 & 0 \\
\hline C. benghalensis & 0 & 0 & 0 & 0 & 0 & 0 & 0 \\
\hline C. prostrata & $6.0 \times 10^{1}$ & $2.3 \times 10^{1}$ & $1.1 \times 10^{1}$ & 0 & 0 & 0 & 0 \\
\hline D. aegyptium & $2.9 \times 10^{1}$ & $1.0 \times 10^{2}$ & $5.8 \times 101$ & $3.7 \times 10^{1}$ & $1.2 \times 10^{1}$ & 0 & 0 \\
\hline D. horizontalis & $9.6 \times 10^{2}$ & $3.2 \times 10^{1}$ & 0 & 0 & 0 & 0 & 0 \\
\hline E. heterophylla & 0 & $2.5 \times 10^{2}$ & $4.4 \times 10^{2}$ & 0 & 0 & 0 & 0 \\
\hline M. alternifolius & 0 & $2.1 \times 10^{3}$ & $8.6 \times 10^{2}$ & $3.9 \times 10^{2}$ & $5.0 \times 10^{2}$ & 0 & 0 \\
\hline M. cochinchinensis & 0 & 0 & 0 & 0 & 0 & 0 & 0 \\
\hline P. angulata & 0 & $1.1 \times 10^{1}$ & 10 & 0 & 0 & 0 & 0 \\
\hline P. lappacea & $3.9 \times 10^{1}$ & 0 & $3.0 \times 10^{1}$ & $5.6 \times 10^{2}$ & $1.1 \times 10^{3}$ & 0 & 0 \\
\hline S. nigrum & 0 & $1.1 \times 10^{3}$ & $1.5 \times 10^{3}$ & $9.9 \times 10^{2}$ & $1.0 \times 10^{2}$ & 0 & 0 \\
\hline T. triangulare & 0 & 8 & $2.0 \times 10^{1}$ & $2.1 \times 10^{1}$ & $2.8 \times 10^{1}$ & 0 & 0 \\
\hline T. procumbens & 0 & 0 & $8.1 \times 10^{1}$ & $4.1 \times 10^{1}$ & $2.6 \times 10^{1}$ & 0 & 0 \\
\hline V. cinerea & * Colony forming units (CFU) mean of two plates deriving from serial dilutions. & 0 & 0 \\
\hline
\end{tabular}

Table 3:- Development of epiphytic Xam populations on different weed species under glasshouse conditions after infiltration of leaves with a bacterial suspension of $10^{7}$ cells $/ \mathrm{ml}$ of the highly virulent strain GSPB 2511

\begin{tabular}{|c|c|c|c|c|c|c|c|}
\hline \multicolumn{8}{|c|}{ CFU/g leaf fresh weight* } \\
\hline Weed species & 1 day** & 15 days & 25 days & 30 days & 45 days & 60 days & 75 days \\
\hline B. deflexa & $4.8 \times 10^{3}$ & $2.1 \times 10^{4}$ & $3.3 \times 10^{4}$ & $5.9 \times 10^{4}$ & $1.4 \times 10^{4}$ & $7.3 \times 10^{3}$ & 0 \\
\hline C. mimosoides & $6.9 \times 10^{2}$ & $5.0 \times 10^{3}$ & $1.4 \times 10^{2}$ & 0 & 0 & 0 & 0 \\
\hline C. erecta & $1.1 \times 10^{4}$ & $3.7 \times 10^{4}$ & $1.6 \times 10^{5}$ & $1.9 \times 10^{3}$ & $4.0 \times 10^{1}$ & 0 & 0 \\
\hline D. aegyptium & $1.2 \times 10^{3}$ & $2.2 \times 10^{3}$ & $1.1 \times 10^{3}$ & $2.3 \times 10^{3}$ & $7.5 \times 10^{2}$ & $1.6 \times 10^{3}$ & 0 \\
\hline D. horizontalis & $6.6 \times 10^{4}$ & $2.9 \times 10^{5}$ & $3.1 \times 10^{4}$ & $4.0 \times 10^{4}$ & $3.9 \times 10^{4}$ & 0 & 0 \\
\hline E. heterophylla & $1.9 \times 10^{5}$ & $2.4 \times 10^{6}$ & $4.0 \times 10^{4}$ & $1.7 \times 10^{3}$ & $1.3 \times 10^{2}$ & 0 & 0 \\
\hline M. alternifolius & $2.8 \times 10^{2}$ & $9.6 \times 10^{3}$ & $2.1 \times 10^{4}$ & $3.3 \times 10^{2}$ & $6.3 \times 10^{1}$ & 0 & 0 \\
\hline M. cochinchinensis & $1.0 \times 10^{3}$ & $2.9 \times 10^{4}$ & $1.5 \times 10^{5}$ & $6.3 \times 10^{1}$ & 0 & 0 & 0 \\
\hline P. angulata & $8.2 \times 10^{4}$ & $1.7 \times 10^{6}$ & $4.2 \times 10^{4}$ & $1.5 \times 10^{5}$ & $1.6 \times 10^{5}$ & 0 & 0 \\
\hline P. lappacea & $3.6 \times 10^{4}$ & $1.7 \times 10^{4}$ & $6.8 \times 10^{3}$ & $1.6 \times 10^{2}$ & 0 & 0 & 0 \\
\hline T. triangulare & $4.6 \times 10^{3}$ & $3.2 \times 10^{6}$ & $2.3 \times 10^{6}$ & $5.4 \times 10^{5}$ & 0 & 0 & 0 \\
\hline T. procumbens & $5.9 \times 10^{4}$ & $2.9 \times 10^{6}$ & $2.5 \times 10^{5}$ & $1.7 \times 10^{4}$ & 0 & 0 & 0 \\
\hline V. cinerea & $1.2 \times 10^{4}$ & $6.0 \times 10^{5}$ & $2.0 \times 10^{5}$ & $9.2 \times 10^{5}$ & $1.1 \times 10^{3}$ & $1.7 \times 10^{4}$ & 0 \\
\hline \multicolumn{7}{|l|}{ Colony forming units (CFU) mean of two plates deriving from serial dilutions. } \\
\hline
\end{tabular}

Table 4:- Survival of Xam in soil contaminated by a bacterial suspension of the strain GSPB 2506

\begin{tabular}{|c|c|}
\hline Time* & Mean CFU/g** \\
\hline 0 day & $1.5 \times 10^{6}$ \\
\hline 1 week & 4 \\
\hline 2 weeks & 0.06 \\
\hline 3 weeks & 0.06 \\
\hline 4 weeks & 0 \\
\hline 5 weeks & 0 \\
\hline
\end{tabular}

* Weeks after contamination of soil in pots by a bacterial suspension at the concentration of $10^{8}$ cells $/ \mathrm{ml}$. ** Means are the average of three replications and indicate living Xam populations at each sampling date. 


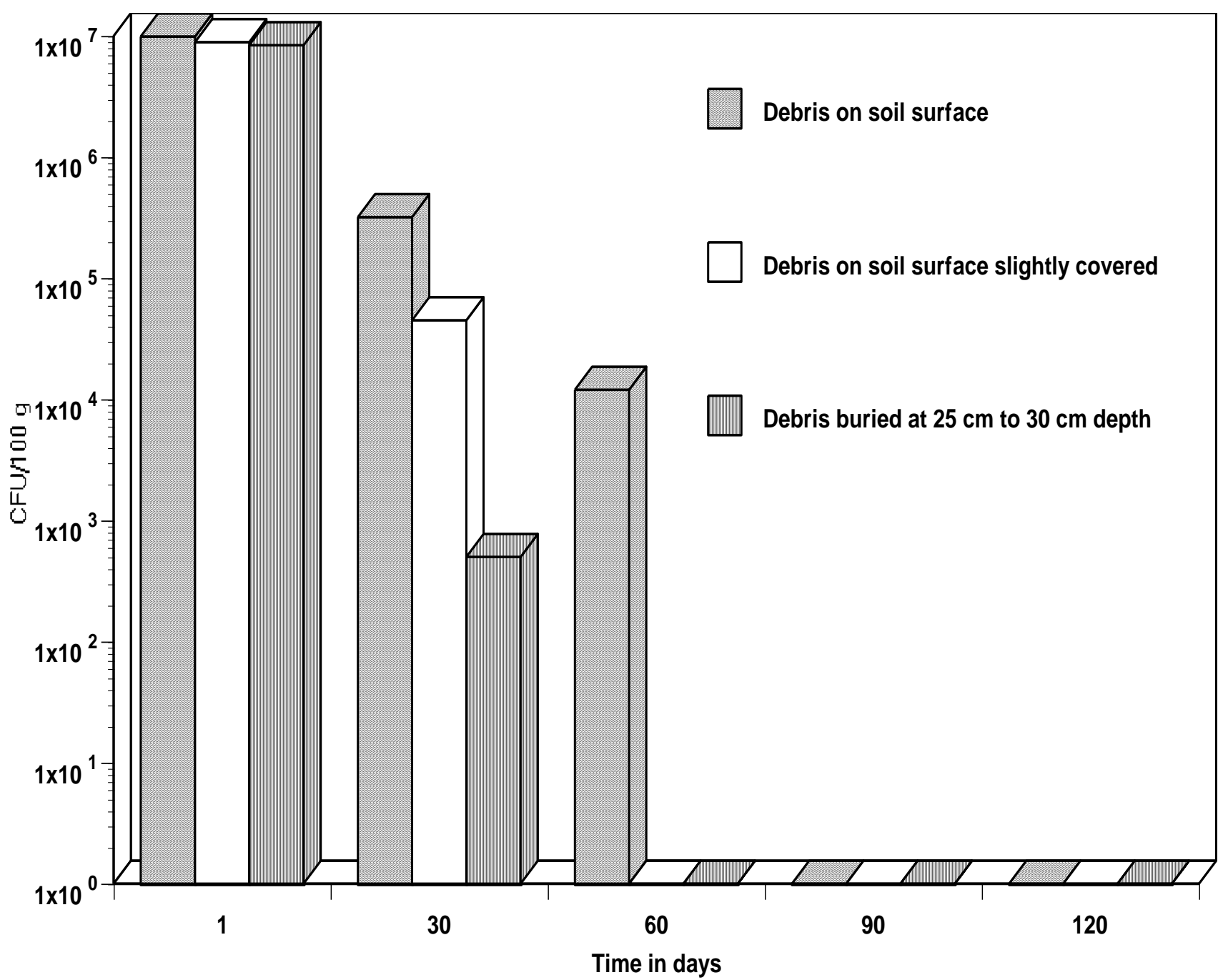

Figure 1:- Survival of Xanthomonas axonopodis pv. manihotis in cassava debris in or on soil under field conditions without shadowing in 1996. Colony forming units (CFU) indicate the living Xam populations per treatment at each sampling date. 


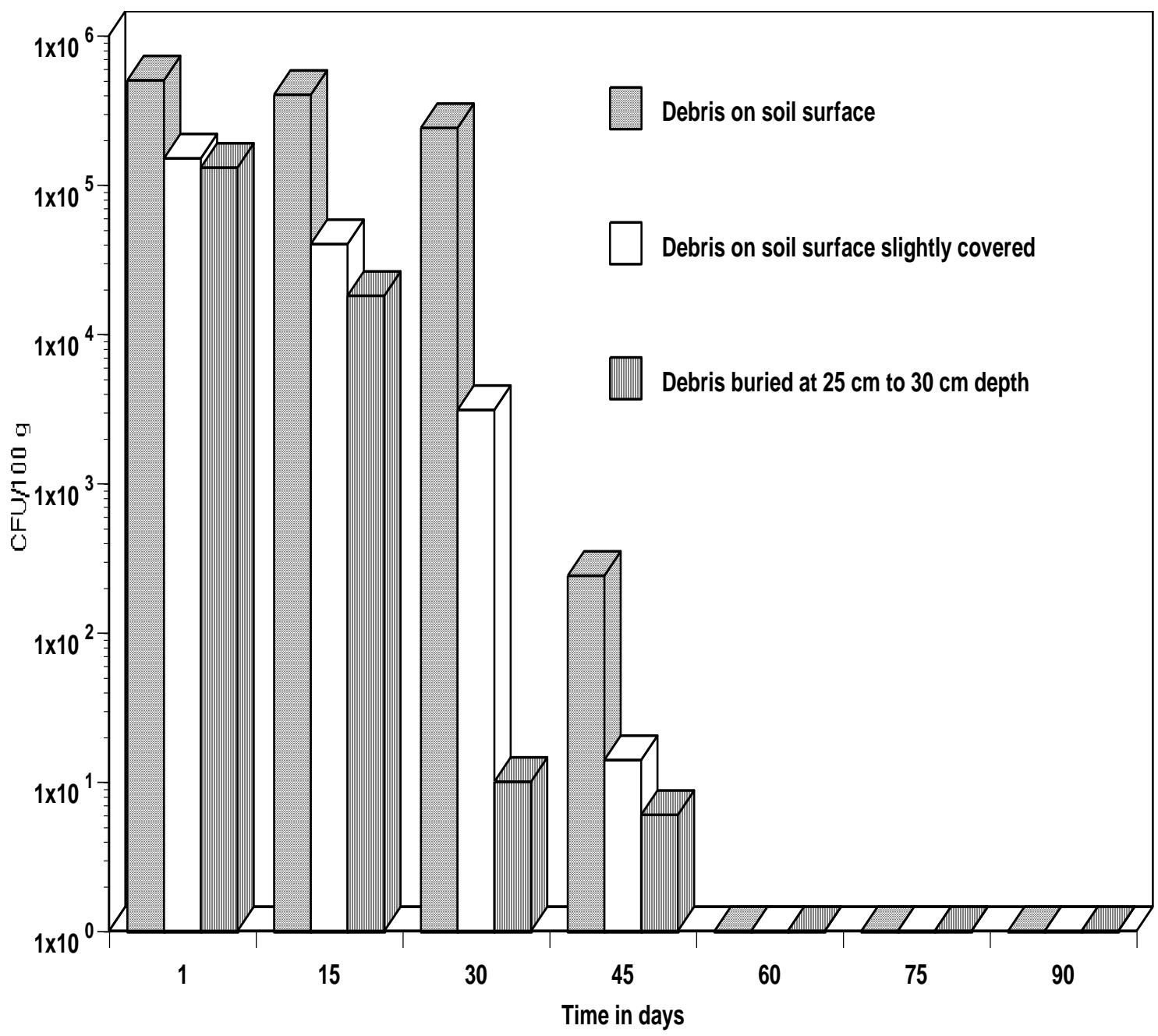

Figure 2:- Survival of Xanthomonas axonopodis pv. manihotis in cassava debris in or on soil at field conditions under shaded conditions in 1997. Colony forming units (CFU) indicate the living Xam populations per treatment at each sampling date. 


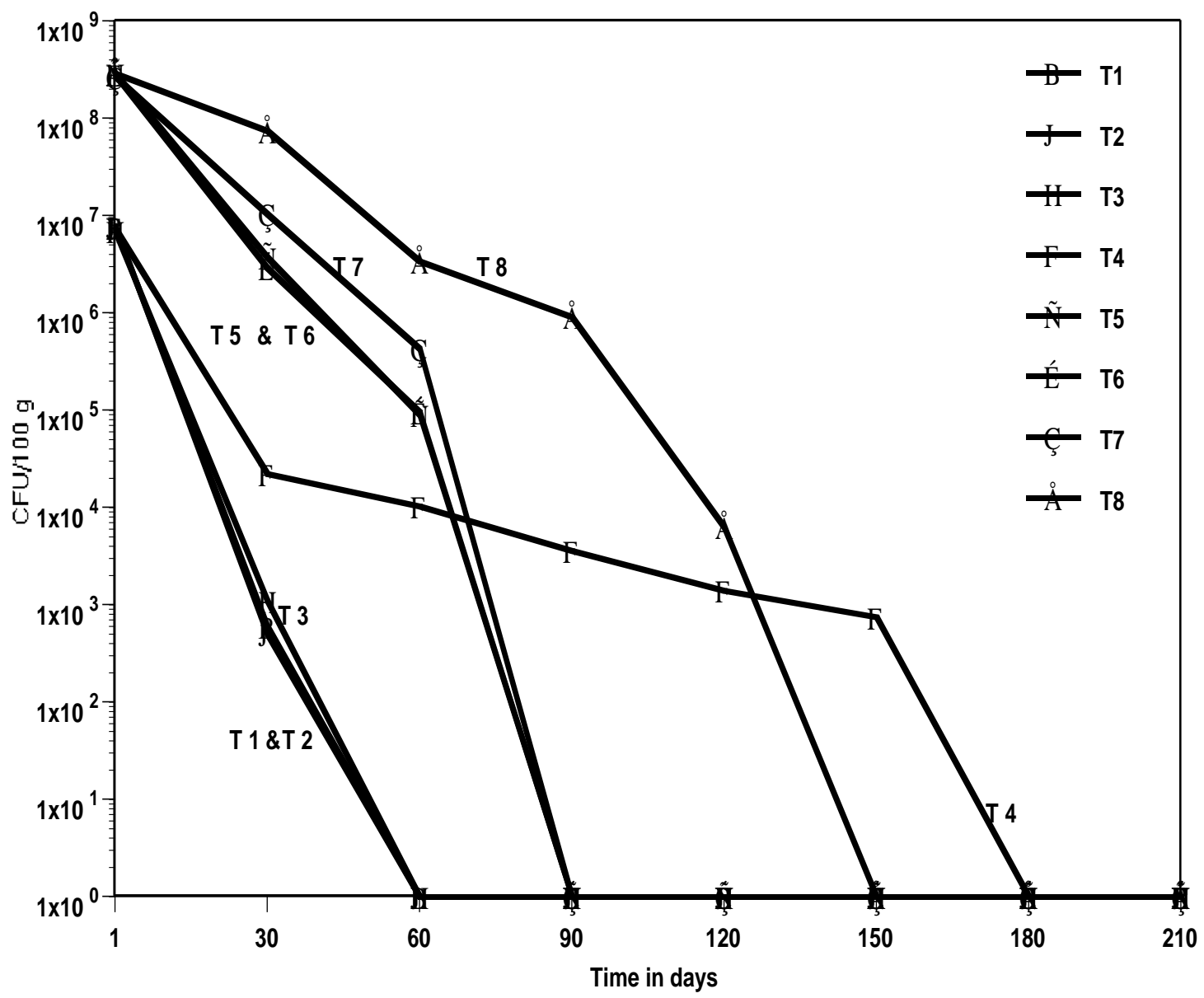

Figure 3:- Survival of Xanthomonas axonopodis pv. manihotis in cassava debris in soil in pots with different water regimes under glasshouse conditions. Colony forming units (CFU) indicate the living Xam populations per treatment at each sampling date.

$\mathrm{T} 1=$ Infected leaves mixed with soil, watered three times per week during 6 months and then not watered

$\mathrm{T} 2=$ Infected leaves mixed with soil, watered three times per week during 12 months

$\mathrm{T} 3$ = Infected leaves mixed with soil, watered three times in one week, not watered during the following week, followed by alternate weekly watering and not watering

$\mathrm{T} 4=$ Infected leaves mixed with soil and kept without watering

$\mathrm{T} 5=$ Infected leaves, watered three times per week during 6 months and then not watered

T6 $=$ Infected leaves, watered three times per week during 12 months

$\mathrm{T} 7$ = Infected leaves, watered three times in one week, not watered the following week, followed by alternate weekly watering and not watering

T8 $=$ Infected leaves without watering 


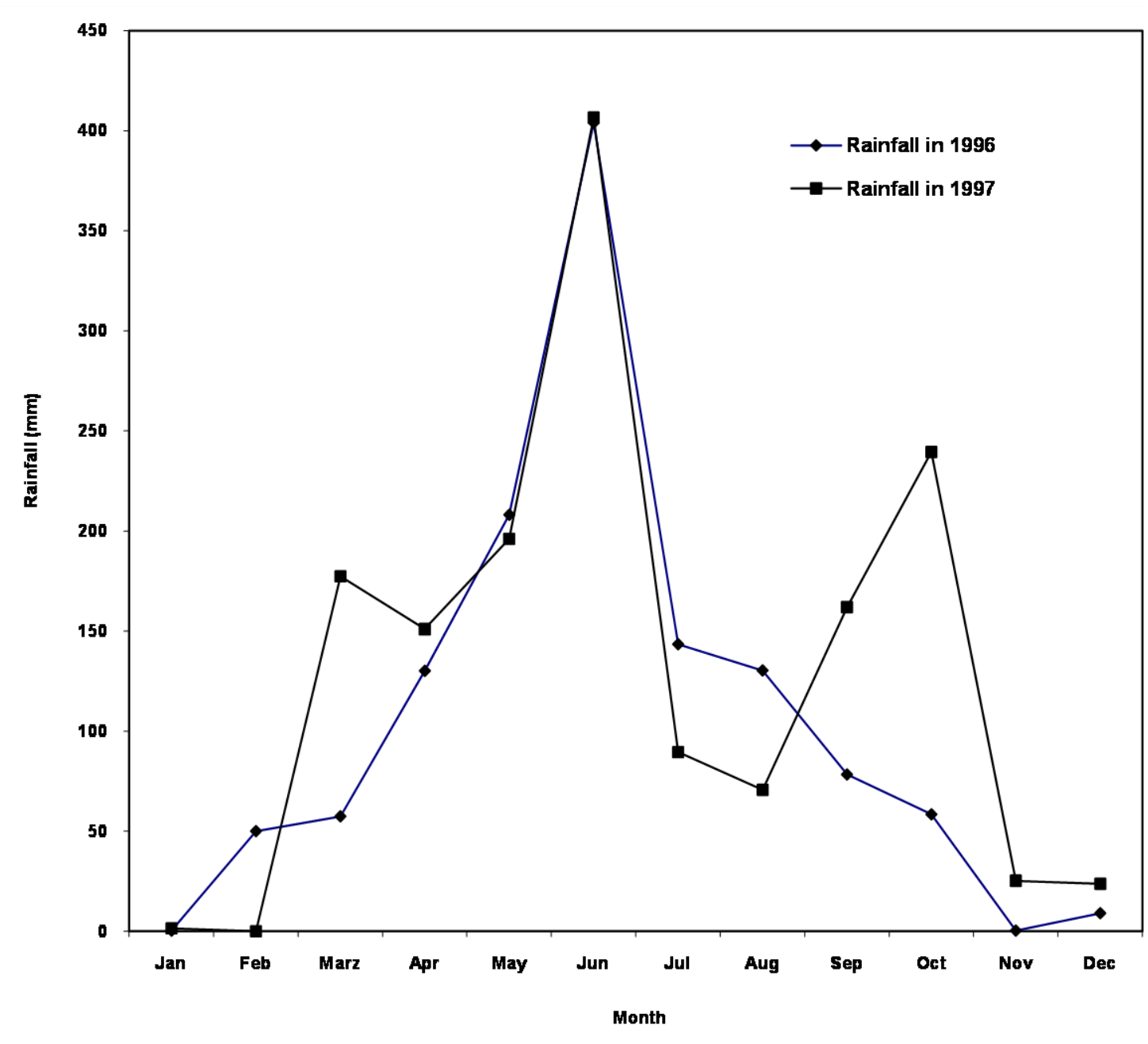

Figure 4:- Rainfall distribution t the IITA station in Abomey-Calavi, South Benin, in 1996 and 1997

\section{Acknowledgments:-}

The studies were funded by the Federal Ministry for Economic Cooperation and Development, Bonn, Germany.

\section{Literature Cited:-}

1. Akobundu, I. Okezie (1990): The role of weeds control in integrated pest management for tropical root and tuber crops. In: Integrated Pest Management for Tropical Root and Tuber Crops. Proc. of the Workshop on the Global Status of and Prospects for Integrated Pest Management of Root and Tuber Crops in the Tropics. 25 - 30 October 1987. Ibadan, Nigeria. Editors: Hahn, S.K. and Caveness, F.E. pp. 23-29.

2. Akobundu, I. Okezie and Agyaka, C.W. (1987): A Handbook of West African Weeds. International Institute of Tropical Agriculture. $521 \mathrm{p}$.

3. Amusa, T., Ikotun, T. and Hahn, S.K. (1992): Survival of Xanthomonas campestris pv. manihotis in soils under Mucuna fallow. In: Proc. 4th Symposium, ISTRC-AB, held in Kinshasa, Zaire, 5 - 8 December 1989. Editors: Akoroda, M.O. and Arene, O.B. pp. 193-196.

4. Bani, G. (1990): Interactions Zonocerus variegatus (Orthoptère, Pyrgomorphidae) - manioc au Congo : Bioécologie d'un ravageur vecteur de la bactériose. Thèse de Doctorat. Université de Rennes 1. 195 p. 
5. Boher, B. and Verdier, V. (1994): Cassava bacterial blight in Africa: The state of knowledge and implications for designing control strategies. African Crop Science J., 2 (4): 505-509.

6. Buddenhagen, I.W. (1965): The relation of plant-pathogenic bacteria to the soil. In: Ecology of soil-borne Plant Pathogens. Eds. K. F. Baker, W. C. Synder. Pp. 269-284. Berkeley: Univ. Cal. Press 571 p.

7. Cafati, C.R. and Saettler, A.W. (1980): Role of nonhost species as alternate inoculum sources of Xanthomonas phaseoli. Plant Dis. 64: 194-196.

8. Daniel, J.F. (1991) : Contribution à l'étude de la biologie de Xanthomonas campestris pathovar manihotis (Arthaud-Berthet et Bondar) Starr, agent responsable de la bactériose vasculaire du manioc, Manihot esculenta Crantz. Thèse de Doctorat. Université de Paris-Sud Centre D’Orsay. 177 p.

9. Daniel, J.F. and Boher, B. (1978): Ecology of cassava bacterial blight: Epiphytic survival of Xanthomonas manihotis on aerial parts of the cassava plant. Proc. 4th Int. Conf. Plant Path. Bact., INRA, Angers. 763-771.

10. Daniel, J.F. and Boher, B. (1981): Contamination of cassava flowers, fruits and seeds by Xanthomonas

11. campestris pv. manihotis. In: Proc. 5th Int. Conf. of Plant Pathogenic Bacteria. Cali, Colombia. pp. 614-617.

12. Daniel, J.F. and Boher, B. (1985a): Epiphytic phase of Xanthomonas campestris pv. manihotis on aerial parts of cassava. Agronomie 5: 111-116.

13. Daniel, J.F. and Boher, B. (1985b): Etude des modes de survie de l'agent causal de la bactériose vasculaire du manioc, Xanthomonas campestris pv. manihotis. Agronomie 5: 339-346.

14. Dedal, O.I., Palomar, M.K. and Napiere, C.M. (1980): Host range of Xanthomonas manihotis Starr. Ann. Trop. Res. 2(3): 149-155.

15. Derridj, S. (1996): Nutrients on the leaf surface. In: Aerial plant surface microbiology. Editors: Morris, C.E., Nicot, P. C. and Nguyen-The, C. Plenum Press, New York pp. 25-42.

16. Elango, F. and Lozano, J C. (1980): Transmission of Xanthomonas manihotis in seed of cassava (Manihot esculenta). Plant Disease 64: 784-786.

17. Elango, F.N. and Lozano, J.C. (1981): Epiphytic survival of Xanthomonas manihotis on common weeds in Colombia. Proc. 5th Int. Conf. Plant Path. Bact., Cali, Colombia. pp. 203-209.

18. Fanou, A., Wydra, K. and Rudolph, K. (1998): Role of an insect vector and weeds in epidemiology of cassava bacterial blight. Mitt. a. d. Biol. Bundesanstalt H. 357, 287-288.

19. Fanou, A. (1999): Epidemiological and Ecological Investigations on Cassava Bacterial Blight and Development of Integrated Methods for its Control in Africa. Ph. D. Thesis. Georg-August-University, Göttingen, Germany. Cuverllier Verlag. 199 p.

20. Fanou, A., Wydra, K., Zadjanakou, M., LeGall, P. and Rudolph, K. (2001): Study on the survival mode of Xanthomonas campestris pv. manihotis and the dissemination of cassava bacterial blight through weeds, plant debris and an insect vector. In: Root Crops in the 21st Century. Proc. 7th Trienn. Symp. of the Intern. Soc. for Tropical Root Crops, Africa Branch, held at Cotonou, Benin 11 - 17 October 1998. Editors : Akoroda, M.O. and Ngeve, J.M. Pp. 569-575.

21. Gitaitis, R., Macdonald, G., Torrance, R., Hartley, R., Summer, D.R., Gay, J.D. and Johnson III, W.C. (1998): Bacterial streak and bulb rot of sweet onion: II. Epiphitic Survival of Pseudomonas viriflava in Association with Multiple Weed Hosts. Plant Disease, Vol. 82:8. pp. 935-938.

22. Haug, T. and Mégevand, B. (1989): Mise au point de technologies de support pour la lutte biologique contemporaine. In: La Lutte Biologique: Une Solution Durable aux Problèmes Posés par les Déprédateurs des Cultures en Afrique. Editeurs Yaninek, J.S. et Herren, H.R. pp. 156-161.

23. Hirano, S.S. and Upper, C.D. (1983): Ecology and epidemiology of foliar bacterial plant pathogens. Annual Review of Phytopathology, 21: 243-269.

24. Hokawat, S. and Rudolph, K. (1991): Variation in pathogenicity and virulence of strains of Xanthomonas campestris pv. glycines, the incitant of bacterial pustule of soybean. J. Phytopathology. 131: 73-83.

25. Ikotun, T. (1977): Survival of Xanthomonas manihotis in cassava tissues. Niger. J. Pl. Prot. 3: 31-36.

26. Ikotun, T. (1981): Studies on the host range of Xanthomonas manihotis. Fitopatologia Brasileira 6: 15-21.

27. Ikotun, T. (1982): The survival of Xanthomonas manihotis (Arthaud-Berther) Starr in the soil. Fitopatologia Brasileira 7: 29-36.

28. Jacques, M.-A. (1996): The effect of leaf age and position on the dynamics of microbial populations on aerial plant surfaces. In: Aerial plant surface microbiology. Editors: Morris, C.E., Nicot, P.C. and Nguyen-The, C. Plenum Press, New York pp. 233-248. 
29. Jones, J.B., Pohronezny, K.L., Stall, R.E. and Jones, J.P. (1986): Survival of Xanthomonas campestris pv. vesicatoria in Florida on tomato crop residue, weeds, seeds and volunteer tomato plants. Phytopathology Vol. 76:4, pp. 430-434.

30. Latorre, B.A. and Jones, A.L. (1979): Evaluation of weeds and plant refuse as potentiel sources of inoculation of Pseudomonas syringae in bacterial canker of cherry. Phytopathology 69:1122-1124.

31. Leu, L.S. (1978): Cassava bacterial blight in Taiwan. In: Diseases of Tropical Food Crops, Proc. of an Intern. Symp. U.C.L. Louvain-La-Neuve, Belgium, 1978. Editors: Maraite, H. and Meyer, J.A. pp 119-129.

32. Lozano, J.C. (1986): Cassava bacterial blight: a manageable disease. Plant Disease 70(12): 1089-1093.

33. Lozano, J.C. and Sequeira, L. (1974): Bacterial blight of cassava in Colombia: Etiology. Phytopathology 64: 74-82.

34. de Mackiewiz, D., Gildow, F.E., Blua, M., Fleischer, S.J. and Lukezic, F L. (1998): Herbaceous weeds are not ecologically important reservoirs of Erwinia tracheiphila. Plant Dis. 82: 521-529.

35. Maraite, H. and Meyer, J.A. (1975): Xanthomonas manihotis (Arthaud-Berthet) Starr, causal agent of bacterial wilt and leaf spot of cassava in Zaire. Pans 21: 27-37.

36. Marcano, M. and Trujillo, G. (1982): Bacteriosis de la yuca; identificados algunos aspectos epidemiologicos del pathogeno que pueden utilizarse para disminuir los danos ocasionados par la enfernedad. Fonaiap Divulga [Venezuela], 1: 12-13.

37. Marcano, M. and Trujillo, G. (1984): Perpetuacion de la bacteria Xanthomonas campestris pv. manihotis (Berthet y Bondar) Dye. en el suelo a traves de resto de cosecha. Agronomia Tropical Vol. 34, Nos. 4-6, pp. 719.

38. McCarter, S.M., Jones, J.B., Gitaitis, R.D. and Smitley, D.R. (1983): Survival of Pseudomonas syringae pv. tomato in association with tomato seed, soil, host tissue, and epiphytic weed hosts in Georgia. Phytopathology 74:1393-1398.

39. Persley, G.J. (1977): Technical report on IDRC cassava bacterial blight project. IITA Ibadan, Nigeria. 18 p.

40. Persley, G.J. (1978): Epiphytic survival of Xanthomonas manihotis in relation to the disease cycle of cassava bacterial blight. Proc 4th Int. Conf. Plant. Path. Bact. INRA, Angers. pp. 773-777.

41. Persley, G.J. (1979): Studies on the survival and transmission of Xanthomonas manihotis on cassava seed. Annals of Applied Biology, 93: 159-166.

42. Rhodes, M.E. (1959): The characterization of Pseudomonas fluorescens. J. Gen Microbiol. 21: $221-263$.

43. Rudolph, K. (1993): Infection of the plant by Xanthomonas. In: Xanthomonas. Editors: Swings, J. G. and Civerolo, E.L. Chapman \& Hall, London. pp. 193-264.

44. Schönherr, J. and Baur, P. (1996): Cuticle permeability studies a model for estimating leaching of plant metabolites to leaf surfaces. In: Aerial plant surface microbiology. Editors: Morris, C.E., Nicot, P.C. and Nguyen-The, C. Plenum Press, New York pp. 1-23.

45. Schuster, M.L. and Coyne, D.P. (1974): Survival mechanisms of phytopatogenic bacteria. Annual Review of Phytopathology, vol. 12. Eds. Kenneth, F.B., George, A.Z. and Ellis, B.C. pp. 199-221.

46. Terry, E.R. (1976): Factors affecting the incidence of CBB in Africa. Proceedings of the $4^{\text {th }}$ Symposium of the International Society for Tropical Root Crops. CIAT, Cali, Colombia. pp.179-184.

47. Thaveechai, N., Leksomboon, C., Kositratana, W. and Paradornutwat, A. (1993): Survival of Xanthomonas campestris pv. manihotis under natural field conditions. Kasetsart-Journal, Natural Sciences. 27:1, 25-32.

48. Vauterin, L., Hoste, B., Kersters, K. and Swings, J. (1995): Reclassification of Xanthomonas. Int. J. Syst. Bacteriol. 45: 472-489.

49. Wydra, K., Fessehaie, A., Fanou, A., Sikirou, R., Janse, J.D. and Rudolph, K. (1998): Variability of strains of Xanthomonas campestris pv. manihotis $(\mathrm{Xcm}$ ), incitant of cassava (Manihot esculenta Crantz) bacterial blight, from different geographic origins in pathological, physiological, biochemical and serological characteristics. In: Mahadevan, A. (Editor), Plant Pathogenic Bacteria. Proc. 9th International Conference. Centre for Advanced Study in Botany, University of Madras, India. pp. 317-323. 